\title{
FELSŐOKTATÁS-IRÁNYÍTÁSI ÉS EGYETEMI KORMÁNYZÁSI TRENDEK EURÓPÁBAN
}

\author{
KECZER GABRIELLA
}

Szegedi Tudományegyetem Juhász Gyula Pedagógusképző Kar

A tanulmány az elmúlt évtizedek legfontosabb jelenségeit és változásait mutatja be az európai felsőoktatás kormányzati irányításában és az egyetemek kormányzásában. Foglalkozik a rendszerszinttel, azaz a kormányzati felsőoktatás-irányítás eszközeivel és tendenciáival, valamint az intézményi szinttel, azaz a belső irányítás - kormányzás, menedzsment - kérdéseivel, és a két dimenzió összefüggéseivel. Az elemzés a kormányzati magatartással összefüggésben kitér az egyetemek autonómiájának alakulására, a belső irányítás kapcsán részletesen foglalkozik az irányító testületekkel és a külső tagok szerepével. Az eredmények alapján megállapítható, hogy bár az elmúlt évtizedben radikális változások nem következtek be az egyetemek irányításában - kivételt éppen Magyarország képez -, számos országban jellemző az útkeresés, illetve a finomhangolás.

Kulcsszavak: felsőoktatás-irányítás, autonómia, egyetemi kormányzás, menedzserizmus

The study presents the most important phenomena and changes in steering higher education systems and that of university governance of the last decades in Europe. It deals with both the systemic level - means and trends of steering higher education by the national governments, and the institutional level - governance, management. In relation to the governments' actions, the analysis includes the trends of university autonomy. When discussing university governance, governing bodies and the role of external members are scrutinized. Results indicate that there were no radical changes in the steering and governance of higher education institutions in the last decade - with one exception, Hungary -, but there are several countries where the fine-tuning of the system is still on agenda.

Keywordsł steering of higher education, autonomy, university governance, managerialism

Levelező szerző: Keczer Gabriella, Szegedi Tudományegyetem Juhász Gyula Pedagógusképző Kar, 6727 Szeged, Duna utca 6. E-mail: keczergabriella@gmail.com 


\section{Bevezetés}

A $z$ egyetemek külső, rendszerszintü irányítása (external governance, system-level governance, steering) - a továbbiakban felsőoktatás-irányítás - az állam és a felsőoktatás viszonyára, az állam által alkalmazott irányítási metódusokra, eszközökre utal, és alapvetően meghatározza az egyetemek autonómiáját. Az egyetemek belső kormányzása (internal governance) - a továbbiakban (egyetemi) kormányzás - a belső irányítási struktúrákat, döntéshozatali mechanizmusokat, vezetői szerepeket, irányító testületeket és ezek viszonyát jelenti (Middleburst 2004: 259, idézi Arnhold et al. 2018: 51). A kormányzást az különbözteti meg az intézményi menedzsmenttől (management), hogy a kormányzás esetében a hangsúly a stratégia és intézményi politika meghatározása mögött húzódó struktúrákon és folyamatokon, a funkciók és a hatalom elosztásán van (Eurydice 2008, idézi Arnbold et al. 2018: 51), a menedzsment pedig a szervezeti célok hatékony elérésének biztosítását jelenti a napi mủködésen keresztül, előre meghatározott szabályok alapján (Arnhold et al. 2018: 51). A három dimenzió természetesen szorosan összefügg egymással, mint arra a tanulmányban is utalni fogok.

Folyamatos figyelmünket a felsőoktatás-irányítás és egyetemi kormányzás alakulása iránt az indokolja, hogy ezek kulcsfontosságúak az egyetemek hatékony müködése és küldetésük teljesítése szempontjából. A fenntartóval és hatóságokkal való produktív kapcsolat, a támogató jogszabályi háttér a felsőoktatás-irányításban éppolyan fontos, mint megtalálni a megfelelő egyensúlyt az egyetemi közvélemény bevonása és a hatékony döntéshozatalt, rugalmas és adaptív menedzsmentet lehetővé tévő struktúrák és folyamatok kialakítása között a belső kormányzásban. (Pruvot-Estermann 2018: 638.)

Bár elemzésünkben az általános jelenségekre koncentrálunk, európai tendenciákat azonosítunk, ezeken belül az egyes térségek - például az Egyesült Királyság és gyors követői, a humboldti és a napóleoni rendszer örökösei, a dél-európai és a posztkommunista országok - között továbbra is fontos különbségek fedezhetők fel. Megjelennek a nemzeti sajátosságok is, részben a tradícióknak, részben a nemzeti kormányok eltérő felfogásának köszönhetően. A különbségek fontosságát több kutató hangsúlyozza, illetve magyarázza (például Teichler 2019; Gornitzka-Maassen-de Boer 2017; Donina-Paleari 2018).

\section{A felsőoktatás-irányítás alakulása}

\section{Az állam és a felsőoktatás viszonya a 20. század második felében}

Európában ${ }^{1}$ az 1960-as évekig az állam és a felsőoktatás viszonyát a bizalmi viszony jellemezte: minden szereplő elfogadta, hogy az egyetemek irányítására az akadémiai szféra szereplői a legalkalmasabbak. Ezt követően változás következett be úgy a szemléletben, mint az állam és az egyetemek viszonyában és ennek megfelelően a felsőoktatás irányításában. Az akadémiai irányítás hatékonyságába vetett hit megrendült, a társadalmi

A közép- és kelet-európai államok felsőoktatásának a szocializmus időszakában a nyugati országokétól eltérő jellemzőire a tanulmányban nem térünk ki. 
elvárások megváltoztak. (Carvalho 2018.) Az 1960-as évektől az 1980-as évek elejéig jellemzően erősödött az állam szerepe a felsőoktatás középtávú tervezésében - például a hallgatók számának vagy az egyes intézmények profiljának és képzési portfóliójának meghatározásában -, és részletesebb szabályozás született az egyetemek működésére vonatkozóan. Az 1980-as években először Hollandiában, majd az 1990-es években Európa nagyobb részében, végül a 21. század elején a kontinens többi országában is újra megváltozott a felsőoktatás irányítása: a direkt állami kontroll helyett a felügyelet vált jellemzővé. (Teichler 2019.)

Van Vught (1994) az állami kontroll és az állami felügyelet különbségét a következőképpen ragadja meg:

- Állami kontroll: Az állami bürokrácia erőteljes, az állam beavatkozik a felsőoktatásba történő bekerülés feltételeibe, a tantervekbe, a kimeneti követelményekbe, a vizsgáztatási rendszerbe, az oktatók kinevezésébe és előléptetésébe.

- Állami felügyelet: Az állam bürokratikus beavatkozása kismértékű és közvetett. Az állam szerepe az akadémiai minőség és az intézmények elszámoltathatóságának (accountability) biztosítására korlátozódik. Az állam nem kényszerít részletekbe menő szabályozást és szigorú ellenőrzést a felsőoktatásra. Az állam az oktatás végeredményére és nem a bemenetre vagy a folyamatra koncentrál; az ex-ante szabályozás helyére az ex-post értékelés lép. Az állam szerepe a célok és elvárások meghatározása, ezek teljesítésének módját pedig az intézményekre bízta (Krücken 2011, idézi Arnbold et al. 2018).

Maassen (2017) egy másik állami irányítási modellel írja le a fenti jelenséget. Megkülönbözteti

- a központosított kormányzást, melyben hierarchikus viszony van az állam és az egyetemek között;

- a tárgyalásos kormányzást, ahol a hatalmi dinamikák érvényesülnek; és

- a versenyeztető (competitive) kormányzást, ahol a piaci mechanizmusok jellemzőek.

A szerző szerint először a központosított kormányzástól a felügyelet felé mozdult el a rendszer, majd innen a tárgyalásos kormányzás felé, végül az 1990-es évektől a versenyeztető megközelítés dominált a nemzeti reformtörekvésekben (Maassen 2017).

$\mathrm{A} z$ utóbbi évtizedekben jellemző állami hozzáállást gyakran a „távolból történő irányítás" (steering from a distance) kifejezéssel írják le. Ennek alapját a jogi keretszabályozás, az egyetemek és az állam között létrejövő szerződéses viszony és a pénzügyi elszámoltatás jelenti. Jellemző továbbá a köztes, úgynevezett puffer testületek - például akkreditációs, minőségbiztosítási, teljesítményaudit szervezetek, kutatásfejlesztési tanácsok - megjelenése az állam és az egyetemek között (OECD 2008). A fent részletezett paradigmaváltásban jelentős szerepe volt az úgynevezett „új menedzserizmusnak”. Ennek kulcsfogalmai a teljesítmény-központú vagy megegyezéses eredménycélokkal való vezetés, a hatékonyság, az értékelési kultúra (Braun-Merrien 1999). A kormányzatok a felsőoktatási intézmények magatartását próbálják meg a teljesítménynövekedés irányába befolyásolni azzal, hogy az anyagi ösztönzőket az állam által fontosnak tartott eredményekkel - például hallgatói lemorzsolódás csökkentése, hallgatók foglalkoztathatóságának javítása, kutatási eredmények hasznosulása stb. - kapcsolják össze (McLendon-Hearn-Deaton 2006). Ugyanakkor, ahogyan Stensaker és Harvey (2001) 
rámutat, a kormányok és más éritettek egyre határozottabban teszik fel a kérdést, hogy a felsőoktatás hatékonyan müködik-e, a szektor kellőképpen ösztönzi-e a gazdasági fejlődést, a hallgatók megtanulják-e, amire szükségük van, az egyetemek és főiskolák segítik-e a nemzet modernizációs vagy innovációs törekvéseit. Az elszámoltathatóság és a minőségbiztosítás e kérdések megválaszolását teszik lehetővé. A fenti tendencia tehát nem az állam szerepének csökkenését, hanem annak átalakulását jelenti a felsőoktatásban.

\section{A felsöoktatás-irányitás változásai napjainkban}

Az utóbbi években a következő, a felsőoktatás-irányítással összefüggő változások figyelhetők meg (Pruvot-Estermann 2018 alapján):

- Több országban változott az egyetemek jogi státusa, intézményi formája (például korábbi állami intézmények alapítványi formában működnek tovább), ami általában az államtól való nagyobb függetlenséggel és az egyetemi kormányzásban a külső szereplők fokozottabb szerepvállalásával jár. Ahol azonban ezeket a külső szereplőket kormányzat nevezi ki, illetve ahol a külső szereplők között a közhatóságok képviselői is ott vannak, ott mindez az állam fokozottabb befolyásának is tekinthető az egyetemek belső döntéshozatali mechanizmusára.

- Jelentős különbség az is, hogy van, ahol az egyetemek maguk választják meg az intézményi formát - például Olaszországban és Portugáliában a közintézményi és az alapítványi formák közül választhatnak (Donina-Paleari 2018), Finnországban az állami vállalati (public corporation) és az alapítványi státus közül (Keczer-Kováts 2019), míg máshol (például Magyarország) a kormányzat jelöli ki a státusváltó intézményeket és az új működési kereteket.

- Az állami egyetemek finanszírozása a felsőoktatás-irányítás egyik fontos eszköze. A gazdasági válság hatása egyértelműen érezhető: több országban ismét az irányítás direkt eszközeihez nyúlt a kormányzat, jelentősen nőtt az egyetemek be- és elszámolási kötelezettsége, szigorodtak a gazdálkodásra vonatkozó elöírások.

- Jellemző az állami beavatkozásnak az a formája, hogy a kormányzatok felülről valósítják meg a felsőoktatási szolgáltatások koncentrálását, illetve racionalizálását regionális vagy nemzeti szinten, központi döntéssel vonnak össze intézményeket.

- További jellemzője az állam és a felsőoktatás viszonyának, hogy több országban gyors reformok sorozatát hajtották végre a kormányzatok, kérdésessé téve az egyetemek számára a jogszabályi keretek stabilitását, kiszámíthatóságát.

Néhány országban az állami kontroll ismét erősödött; ilyen például Magyarország a kancellári rendszer bevezetése következtében. (A kancellári rendszerről részletesen lásd Kováts 2016, Kováts 2018; Rónay 2020.) Egyetemi vezetők más államokban is az állami befolyás bizonyos mértékü és formájú növekedését tapasztalják az European University Association (EUA) különböző országokban, egy-egy egyetemi vezetővel készített interjúsorozata szerint. Ilyen például Olaszország is, ahol a megkérdezett vezető szerint az új, 2010-es törvénnyel szorosabbá vált a szabályozás. A megkérdezett egyetemi vezető Norvégiában is úgy érzékeli, hogy bár az egyetemek széles körű autonómiával rendelkeznek, a kormányzati kontroll bizonyos fokozódása figyelhető meg. A franciaországi vezető szerint, a 2007-es új törvények ugyan nagyobb autonómiát biztosítanak az egye- 
temeknek, a kormányzat továbbra is szoros ellenőrzést gyakorol a felsőoktatás felett, így bizonyos szempontból a rendszer nem rugalmasabb, hanem merevebb lett. Dániában a megszólaltatott egyetemi vezető arról számol be, hogy a politikai rendszer részéről gyakran tapasztalnak bizalmatlanságot, a döntéshozók egyedi esetek miatt fokozzák a politikai kontrollt és alkalmaznak részletekbe menő szabályozást, ami rossz és rövidlátó megoldásokat eredményez. (EUA 2015.) Angliában egyértelműen nagyobb és tolakodóbb lett a felsőoktatás szabályozása a 2017-es új keretrendszer következtében. 2018. január elsejével létrejött az úgynevezett Office for Students, az oktatási minisztérium köztestülete, mely a felsőoktatás független versenyhatóságának a szerepét látja el. Mint Shattock (2019: 5) fogalmaz: „Az Office for Students nem egyetembarát testület, hanem hatóság."

\section{Változások az egyetemi autonómiában az elmúlt években}

A felsőoktatás-irányítás alakulása hatással van az egyetemek autonómiájára is. Ezt az EUA által először 2011-ben, majd 2017-ben elkészített University Autonomy Scorecard alapján lehet figyelemmel kísérni. A Scorecard készítői hangsúlyozzák, hogy az egyetemeknek „papíron”, formálisan garantált autonómia és a tényleges függetlenségük között gyakran különbség van. A Scorecard a jogi szabályozásból indul ki, feltételezi, hogy a gyakorlat nem tér el jelentősen a szabályozástól, és nincs lehetősége arra, hogy teljes képet adjon az esetleges eltérő esetekről. A 2010-es állapothoz képest 2016-ra a következőképpen alakult az egyetemi autonómia EUA által definiált négy dimenziója ${ }^{2}$ (Pruvot-Estermann 2017 alapján).

\section{A szervezeti autonómia alakulása}

A szervezeti autonómia alakulásában (amely a szervezeti struktúra alakításának és a vezetők önálló megválasztásának szabadságát írja le) nem mutatható ki egyértelmű tendencia Európában; van, ahol növekedés, van, ahol csökkenés fedezhető fel. Csökkent az egyetemek függetlensége ebben a dimenzióban a következő négy vizsgált rendszerben:

- Magyarországon: a kancellári rendszer 2014-es bevezetésével.

- Irországban: a gazdasági válság hatására bevezetett, de utána is hatályban maradó Employment Control Framework korlátozza az egyetemeket az akadémiai struktúrájuk szabad alakításában és szervezetek létrehozásában.

- Lettországban: az új, 2015-ös szabályozás kiterjesztette a korábban csak állami és önkormányzati társaságokra érvényes szabályozást az egyetemek által létrehozott társaságokra is.

- Észak-Rajna-Vesztfáliában: az új szabályozás szerint a rektort már a miniszter nevezi $\mathrm{ki}$, és részletesebb szabályozás vonatkozik a szenátusra is.

Emelkedett három országban:

- Olaszországban: a 2010-es új törvény szerint például a rektort nem feltétlenül kell az adott egyetemről választani.

A 2017-es Scorecard 22 európai országra, illetve felsőoktatási rendszerre - például német tartományra terjed ki. 
- Litvániában: a 2016-os új törvény szerint az egyetemek maguk választhatják ki a kormányzásba bevont külső tagokat, és a rektor elmozdításához sem kell miniszteri jóváhagyás.

- Svédországban: 2011 óta az egyetemek maguk dönthetnek az akadémiai, döntéshozatali és szervezeti struktúrájukról.

Jelentősen azonban egyetlen országban sem nőtt az egyetemek szervezeti autonómiája.

A pénzügyi autonómia alakulása

Az egyetemek pénzügyi autonómiája sem nőtt a 2010-2016-os időszakban. A korábban észlelt direkt kormányzati irányítás ezen a téren továbbra is jellemző, Magyarországon pedig a kancellári rendszer bevezetésével egyértelműen erősödött.

Több országban változott a tandíjakkal összefüggő szakpolitika: eltörölték Észtországban és Észak-Rajna-Vesztfáliában, a külföldi hallgatók számára bevezették Finnországban, megszüntették a felső plafont Litvániában, meghatározták a kereteit Magyarországon. Az utóbbi két lépés az egyetemek mozgásterének változásával jár, ellentétes irányban a két országban. Az ingatlantulajdonlás terén bizonyos kedvező változások következtek be Finnországban, Franciaországban, Lettországban és Litvániában.

A papíron létező pénzügyi autonómiát a gyakorlatban sok esetben szúkíti az alulfinanszírozottság. A fizetések szabad meghatározása például csak elmélet marad, amíg az intézmények nem tudnak a minimálisan kötelezö bérnél többet fizetni, de ugyanígy jelentőségét veszti a maradvány felhasználásának vagy a hitel felvételének szabadsága akkor, ha nem képződik maradvány, illetve az egyetemek a pénzügyi helyzetük miatt nem kapnának hitelt.

Az egyetemek finanszírozása jellemzően szabad felhasználású formában (block grant) történik, ugyanakkor a címkézés, a fünyíróelven történő csökkentés, a finanszírozás felosztása és más hasonló gyakorlatok elterjedtebbé váltak az utóbbi években, az egyetemek csökkenő költségvetési támogatása miatt. Bár az egyetemek finanszírozása éves keretek között történik, több országban elmozdultak a többéves költségvetés készítésének irányába, elsősorban az állammal kötött teljesítményszerződésekkel összefüggésben - ez kedvező változásnak tekinthető.

\section{A személyügyi autonómia alakulása}

Ebben a dimenzióban érzékelhető a legkevesebb változás 2010 óta. A személyügyek kezelése viszonylag stabil az európai felsőoktatásban, jelentős részben az egyetemi dolgozók közalkalmazotti státusának köszönhetően. Ugyanakkor fontos megjegyezni, hogy bizonyos mértékben eltávolodni látszik a közalkalmazotti rendszertől Ausztria, Luxemburg és Magyarország, az új foglalkoztatási formákkal pedig együtt jár az egyetemek szabadságfokának növekedése a toborzásban, a fizetések megállapításában és az elbocsátásban. Ausztriában 2015 óta az új belépőkkel csak egyéni alkalmazotti szerződést (private employee contract) lehet kötni, így a következő 15 évben várható a közalkalmazotti státusban lévők teljes eltűnése a rendszerből. Luxemburgban az intézményi összevonások után már csak az egyetemi dolgozók $10 \%$-a van közalkalmazotti státusban. Magyarországon az alapítványivá alakított egyetemen megszűnt a dolgozók közalkalma- 
zotti státusa. 2016-ban 13 olyan rendszer szerepelt a felmérésben, amelyben a vezető oktatók jellemzően nem rendelkeznek közalkalmazotti státussal, és 16 olyan, ahol igen.

Bizonyos, korábban is viszonylag jelentős személyzeti autonómiával rendelkező rendszerekben tovább nőtt az egyetemek függetlensége ezen a téren, ilyen Luxemburg, Lengyelország és Svédország, ahol a toborzásban és a fizetések megállapításában kaptak nagyobb mozgásteret az egyetemek. Magyarországon az egyetemi kormányzat átalakítása szúkítette a személyügyi autonómiát, Írországban pedig a pénzügyi megszorítások.

\section{$\mathrm{A} z$ akadémiai autonómia alakulása}

Ebben a dimenzióban érzékelhető a legnagyobb elmozdulás - a nagyobb önállóság irányába. Ez jelentős részben az akkreditáció megváltozásával függ össze: a programakkreditáció helyét számos felsőoktatási rendszerben - bár eltérő mértékben és feltételekkel - átveszi az intézményi akkreditáció (Németország, Svájc, Dánia, Lengyelország, Portugália, Flandria, Svédország, Szlovénia), illetve nyolc olyan rendszer is van (Ausztria, Svájc, három német tartomány, Magyarország, Finnország, Észtország), amelyikben az intézmények maguk választhatnak auditort - nem feltétlenül az adott országból, hanem az European Association for Quality Assurance tagok közül. Magyarországon 2015 óta van erre lehetőség.

Csökkenő akadémiai autonómia csak néhány rendszerben érzékelhető, például a hallgatók létszámának meghatározásában. Ausztriában 2010-ben a hallgatói létszámkorlátozást újabb képzési területekre terjesztették ki; Dániában 2014-ben a diplomás munkanélküliség miatt eltörölték az egyetemek szabadságát a hallgatói létszám meghatározásában; Lengyelországban 2011-ben 2\%-ban rögzítették a hallgatói létszám bővítésének arányát. Angliában és Észtországban viszont növekedett az egyetemek szabadsága e téren. A másik, az akadémiai autonómiát szűkítő jelenség az új képzési programok indításának központi korlátozása. Ilyen állami intézkedést vezettek be Flandriában átmeneti jelleggel 2015-2017 között. Lengyelországban viszont a 2011-es szabályozás éppen teljes szabadságot adott az egyetemeknek e tekintetben.

\section{Az egyetemi kormányzás alakulása}

\section{A felsőoktatás-irányitás és a belső kormányzás összefüggései}

A felsőoktatás-irányítás, az állam és az egyetemek viszonyának átalakulása szükségszerűen együtt jár az intézmények belső kormányzásának és menedzsmentjének változásával. A távolról történő állami kormányzás és a felügyelet nemcsak az egyetemi autonómia növekedésével, hanem az elszámoltathatóság, a transzparencia és a hatékonyság követelményének fokozottabb megjelenésével is jár. Ezek pedig új kormányzási és menedzsmentstruktúrákat és -folyamatokat hívnak életre. Az azonban, hogy az új kormányzási rendszert az intézményeknek az állam írja elö, vagy - kisebb-nagyobb mértékben - maguk alakíthatják ki, éppen a felsőoktatás-irányítás jellegétől, az állam felfogásától függ.

A felsőoktatás-irányítás és a belső kormányzás egyik legfontosabb összefüggése tehát az, hogy az egyetemek mekkora szabadságfokkal rendelkeznek a saját kormányzási rendszerük alakításában: szabadon dönthetnek a belső döntéshozatali mechanizmusok- 
ról, a hatáskörök megosztásáról, az irányító testületekről, vagy mindezt a felsőoktatásirányítás jogszabályokban írja elő számunkra. A 2010-es évtized második felében kevés olyan nemzeti felsőoktatási rendszer van, amelyben az intézmények szabadon dönthetnek a kormányzási rendszerükről. Az irányító testületekre vonatkozóan jellemzően központi szabályozás van érvényben. Van, ahol pontosan elöírják például a tagok számát (ilyen többek között Magyarország, Luxemburg, Hollandia, Észtország, Írország, Norvégia, Svédország), máshol csak a minimum/maximum létszámot vagy bizonyos arányokat írnak elő (Belgium, Dánia, Észak-Rajna-Vesztfália, Finnország, Horvátország, Olaszország, Lengyelország, Portugália, Szerbia). A board típusú testületek összetételét a külső tagok arányára vonatkozóan minden országban központilag szabályozzák, és van, ahol a külső tagok profilját, elvárt kompetenciáit is meghatározzák (Dánia, Horvátország, Magyarország, Izland, Olaszország, Írország, Luxemburg, Szerbia). Kivételt jelent az Egyesült Királyság, ahol az egyetemek maguk dönthetnek az irányító testületeikröl. (Pruvot-Estermann 2018.)

A korábbinál szigorúbb szabályozás előrelépést is jelenthet. Olaszországban például a 2010-es törvény rögzítette a board és a szenátus maximális létszámát és rendezte a felelősségi köröket, megszüntetve ezzel azt a gyakorlatot, hogy az egyetemek nagy, adott esetben 100 fó feletti létszámú, kevésbé hatékony és gyakran párhuzamos funkciójú testületeket müködtettek (Pruvot-Estermann 2018). Megfigyelhető, hogy amennyiben a jogszabály választási lehetőséget biztosít számukra, az egyetemek inkább a tradicionális megoldások mellett döntenek. Észak-Rajna-Vesztfáliában például a törvény nem szabályozza a külső tagok bevonását az irányító testületbe, és az egyetemek nem is élnek ezzel a lehetőséggel (Pruvot-Estermann 2018). Ez az attitűd nemcsak az irányító testületekre, hanem általánosságban is jellemző, Portugáliában és Olaszországban az új jogszabályok alapján az egyetemek megválaszthatják a státusukat, de 14 portugál egyetemből mindössze 5 tért át 2017-ig az alapítványi formára, és egyetlen olasz egyetem sem választotta ezt az utat (Donina-Paleari 2018).

\section{Az egyetemi kormányzás evolúciója a felsőoktatás-irányitás változásaival összefüggésben}

Barakonyi (2004) szerint az egyetemek kormányzása annak függvényében alakul, hogy az adott országban az állam, a piac és az akadémiai közösség között milyen viszonyrendszer alakul ki.

1960-ig a kontinentális Európára a hagyományos kormányzási modell volt a jellemző, amely megfelelt az erőteljes állami ellenőrzés melletti szűk egyetemi autonómiának. Az intézményen belül a professzorok, az úgynevezett akadémiai oligarchia hatalma, döntési hatásköre jóval nagyobb volt, mint az intézmény vezetéséé (Clark 1998). A rektor tényleges hatalma csekély volt, inkább első volt az egyenlők - a többi egyetemi profeszszor - között („primus inter pares”), mint egzekutív vezetö (Bleiklie-Kogan 2007). Nagymértékben függött a professzorok érdekeitől (Capano-Regini-Turri 2016). A szenátus szava szinte minden kérdésben meghatározó volt (Clark 1998). A szenátus kollektív módon, konszenzusos alapon hozott döntéseket, tagjait - többségében oktatók, kisebb részben hallgatók és az adminisztratív dolgozók egy-egy képviselője - demokratikusan választja az akadémiai közösség. A külső tagok jelenléte a kormányzásban nem volt jel- 
lemző. (Donina-Paleari 2018.) Az adminisztratív vezetői posztok egy részét oktatók töltötték be másodállásban.

Ahogyan az állami irányítás megváltozott, és az egyetemek autonómiája megnőtt, az egyetemi kormányzásnak is át kellett alakulnia, hogy meg tudjon birkózni a nagyobb felelősséggel és az új kihívásokkal. Az 1980-as évektől az állami kontroll csökkenésével a tradicionális kollegiális vezetést felváltotta az úgynevezett menedzserizmus. A menedzserizmus az egyetemeken olyan új kormányzási módot jelent, amelyet az autokratikus kontrollal, a hatékonyság, az outputok és a bevételek maximalizálására való törekvéssel lehet jellemezni (Tapanila-Siivonen-Filander 2018: 2). Ez a folyamat az Egyesült Királyságból indult, de a 90-es években a legtöbb nyugat-európai országban is elterjedt. A menedzserizmus magában foglalja

- az egyetemek központi irányításának (felsővezetésének) erősödését;

- a külső szereplők megjelenését, illetve szerepének erősödését az egyetemirányításban, ezzel párhuzamosan a professzorok formális befolyásának csökkenését;

- a professzionális intézményvezetési módszerek elterjedését;

- az adminisztratív funkciók és a személyzet bővülését;

- az objektív teljesítményindikátorokon alapuló értékelések általánossá válását. (Teichler 2019: 5-10.)

A távolból történő állami irányítás olyan egyetemeket feltételez, amelyek képesek egyetlen integrált intézményként müködni. Ez több ország egyetemein szervezeti átalakításokat, átláthatóbb és hatékonyabban menedzselhető struktúra, nagyobb méterü szervezeti egységek kialakítását hozta magával. Az elszámoltathatóság követelménye a felsővezetés fentebb már említett erősödése és a kollegiális testületek visszaszorulása mellett az egyéni felelösség növekedését, a hierarchizált és tényalapú döntéshozatalt is magával hozta. Az elszámoltathatóság és az átláthatóság követelménye, valamint a minőségbiztosítás bevezetése az adatgyűjtés és adatszolgáltatás, a belső folyamatok szabályozásának és nyomon követésének professzionálisabbá válását kívánja meg. Megfigyelhető továbbá az intézményi célok explicit megfogalmazása és dokumentálása, a tervezés, a stratégiai gondolkodás előtérbe kerülése. Az egyetemek új feladatai (stratégiai tervezés, minőségbiztosítás, nemzetköziesítés, regionális szerepvállalás, technológiatranszfer, információmenedzsment stb.) a szervezeti struktúra differenciálódását eredményezték, a felsővezetésben is megjelentek ezek felelősei pl. új típusú rektorhelyettesi, igazgatói posztok létesítésével. Az adminisztratív irányításban is létrejöttek az új típusú szervezeti egységek (pl. technológiatranszfer irodák), és van, ahol a teljes szervezetet átalakították mátrix struktúrává. Mindez együtt járt a vezetők profiljának, kompetenciáinak átalakulásával, a menedzsmenthez értő szakemberek jelentőségének növekedésével az intézményirányításban. Míg bizonyos menedzsmentpozíciókat korábban oktatók láttak el további megbízással, általánosabbá vált a fóállású, professzionális vezetők alkalmazása ezeken a posztokon. A megváltozott elvárások új attitűdöt igényelnek az adminisztratív egységektől is: a korábbi bürokratikus szemlélet helyett a szolgáltatói magatartás lett elvárás. (Arnhold et al. 2018.)

Ezzel együtt a felsővezetők pozícióba kerülésének módja is megváltozott. A hagyományos, belső szereplők általi megválasztás (election) mellett az irányító testület vagy minisztérium általi kinevezés (appointment) is általános gyakorlat, de van példa arra is, hogy fejvadász segítségével kutatják fel a legmegfelelőbb külső jelöltet. (Kloster et al. 
2016, idézi Arnhold et al. 2018.) Az angliai és a hollandiai egyetemek például elkezdtek a tengerentúlról, a nemzetközi munkaerőpiacról toborozni olyan felsővezetőket - kancellárokat, elnököket -, akiknél meghatározó a meglévő menedzseri tapasztalat (Donina-Paleari 2018).

Gornitzka és szerzőtársai az egyetemi kormányzás terén bekövetkező változásokat a következő „elmozdulásokkal” írják le:

- a demokratikustól az egzekutív hatalom felé,

- a belsőtől a vegyes (külső és belső) szereplők dominanciája felé,

- a decentralizálttól a centralizált hatáskörök felé,

- a kollektívtől az egyéni felelösség felé (Gornitzka-Maassen-de Boer 2017: 278).

Bár a menedzserizmus és a kormányzási rendszer átalakítása kétségtelenül együtt járt a professzorok hatalmának csökkenésével, Bleiklie és szerzőtársai arra hívják fel a figyelmet, hogy a professzorok - bár befolyásuk a stratégiai döntésekben visszaszorult - továbbra is ott vannak a felsővezetői pozíciókban, és a „puha kormányzás” (soft steering) módszerével képesek irányítani az intézményt (Bleiklie et al. 2011, idézi Carvalho 2018: 3). Hatáskör helyett legitimitásukat és presztízsüket használják, ami jól működik a bizonyos országokban továbbra is jellemző konszenzusorientált szervezeti kultúrában és döntéshozatalban.

Utalva a korábban már idézett Barakonyi-állításra, nemcsak a kormányzat, hanem a piac is hatással van az egyetemi kormányzásra (Barakonyi 2004). A verseny a forrásokért, a hallgatókért, a vezető tudósokért a piaci szempontok erőteljes megjelenését hozta az egyetemek belső irányításában. Ezzel párhuzamosan tetten érhető, hogy a marketingért, a toborzásért, a támogatásszerzésért stb. felelős adminisztratív egységek beleszólást kérnek azokba az akadémiai kérdésekbe, amelyek befolyásolják az egyetem teljesítményét a fenti területeken. Shattock (2019: 6) egy angol oktató tapasztalatait idézve leírja, hogy a központi marketingosztály arra használja a hatáskörét, hogy átalakítsa a kurrikulumot, megvétózzon bizonyos szakmai döntéseket, kikényszerítsen másokat, ügynökségek révén toborozzon hallgatókat. Ezt nem lehet másként tekinteni, mint a menedzsment beavatkozásaként az oktatásba.

Egyre több országban előforduló jelenségnek tűnik Európában, hogy bizonyos intézmények másoktól eltérő státusba kerülnek (például más jogi formában müködnek), és ezzel együtt a kormányzási rendszerük is eltér a többiekétől. Magyarország mellett ez történt Észtországban is 2012-ben és 2014-ben, amikor a hat egyetemből kettő saját, a felsőoktatási törvénytől eltérő szabályozást kapott. E szabályozások nemcsak létrehozták a boardot, de a szenátusnál nagyobb hatáskört is adtak nekik (Pruvot-Estermann 2018).

\section{Az irányitó testületek jellemzői napjainkban}

$\mathrm{A} z$ irányító testületek tekintetében kétféle rendszer figyelhető meg. $\mathrm{A} z$ unitárius modellben egy testület birtokolja a döntési hatásköröket, ${ }^{3}$ ez az egy testület lehet szenátus jellegű (nagyobb létszám, oktatók, hallgatók) vagy igazgatótanács (board) jellegű (kisebb

Ez nem jelenti azt, hogy nem lehetnek egyéb testületek (például a board mellett szenátus Dániában, Izlandon és Portugáliában), ezek azonban csak tanácsadó szerepkörrel rendelkeznek. 
létszám, heterogénebb összetétel). ${ }^{4} \mathrm{~A}$ duális rendszerben ezzel szemben a kétféle testület megosztva birtokolja a döntéshozatali hatáskört. Ezen belül megkülönböztethető a tradicionális és az aszimmetrikus modell. A tradicionális modellben a szenátus és a board is közel azonos súlyú, igaz, eltérő szereppel bír; a szenátus akadémiai, a board jellemzően stratégiai és pénzügyi kérdésekben illetékes. Az aszimmetrikus rendszerben ezzel szemben valamelyik testület szerepe az egyetemirányításban nagyobb, de a másik is rendelkezik döntési jogosultsásokkal. (Pruvot-Estermann 2018.)

A 2010-es évtized második felében az európai országok kisebb hányadában jellemző az unitárius modell, és ezen belül is kevesebb országban (Észtország, Írország, Lengyelország) müködik szenátus típusú testület. Az unitárius rendszerek többségében (Belgium, Dánia, Izland, Norvégia, Portugália) board típusú testület van. Izland a legutóbbi években az egyetemek kérésére szabadult meg a nagylétszámú, képviseleti jellegű testületektől. Az európai államok nagyjából 2/3-ában duális modell van. Ezen belül tradicionális hatáskörmegosztás jellemző a duális rendszerek közel felében (Ausztria, Észak-Rajna-Vesztfália, Olaszország, Egyesült Királyság, Szerbia, Szlovákia, Szlovénia), míg a duális rendszerek másik felére az aszimmetrikus modell jellemző. Felülről tekintve a különböző rendszerekre azt láthatjuk, hogy a vizsgált országok 2/3-ában a hatáskörök jelentős része egy testület kezében van - vagy unitárius, vagy duális, de aszimmetrikus modellben. Vagyis jellemző a hatalomkoncentráció az egyetemi kormányzásban. Ezen belül a board típusú testületek kétszer olyan gyakran jutnak vezető szerephez, mint a szenátusok. (Pruvot-Estermann 2018.)

A tendenciák is ebbe az irányba mutatnak: az egyetemi kormányzási rendszerek Európában egyre nagyobb hatalmat adnak a boardoknak. Ez történt a legutóbbi időszakban például Észtországban, Litvániában, Olaszországban és Csehországban is. (Pruvot-Estermann 2018.) Angliában az irányító testületek immár nemcsak a pénzügyi és stratégiai ügyekben döntenek, hanem az ő felelősségük az is, hogy garantálják az akadémiai standardokat és a hallgatói élményt. Ez felülírja azt az elvet, hogy az akadémiai kérdések a szenátus hatáskörébe tartoznak, és a kormányzókat és irányító testületeket mélyen beleviszi az oktatással összefüggő ügyekbe. (Shattock 2019: 5.)

A testületek szerepének, súlyának, egymáshoz való viszonyának optimális kialakítása nem egyszerű feladat; vannak országok, ahol a folyamatos útkeresés a jellemző. Franciaországban az egyetemi kormányzás az unitárius rendszerből alakult duális aszimmetrikus rendszerré, de míg a 2007-es törvény alapján a board a stratégiai, menedzsment- és HR-kérdésekben is meghatározó szerephez jutott, a 2013-as jogszabály bizonyos hatásköröket, például személyzeti kérdésekben, visszaadott a szenátusnak (Pruvot-Estermann 2018). Dániában a 2003-as törvény radikális elmozdulást jelentett az egyéni felelősség és irányítás felé, a 2011-es módosítás viszont bizonyos mértékig erősítette az egyetemi kormányzás kollektív dimenzióját ${ }^{5}$ (Gornitzka-Maassen-de Boer 2017). Hollandiában a hallgatók és a dolgozók 2015-ben tiltakozásokat szerveztek az

4 A gazdasági-társadalmi szereplők bevonásán alapuló egyetemi kormányzási rendszer a többségében külső szereplőkből álló boardokkal az amerikai felsőoktatásban alakult ki. Nyugat-Európában csak a 20. század végén, Közép-Kelet Európában pedig csak a rendszerváltozás után jelentek meg ezek a testületek. Ezekben a térségekben addig csak a belső szereplők - vezetők, professzorok, oktatók, hallgatók - vettek részt az egyetemek kormányzásában, eltérő és változó hatalommegosztás mellett. (Részletesen lásd Keczer 2010, 2014, 2015).

5 A hivatkozott kutatás a Koppenhágai Egyetem kormányzási rendszerét vizsgálta. 
ellen, hogy az egyetemek egyre inkább a gazdasági érdekeket tartják szem elött, háttérbe szorítva az akadémiai szempontokat. Ennek hatására a holland oktatási minisztérium kezdeményezte a hatáskörmegosztás módosítását az egyetemeken. Bizonyos kérdésekben (személyzeti politika, költségvetés) döntési jogokat adtak vissza a hallgatóknak és az oktatóknak, a végrehajtó testület és az intézményvezetés hatásköreinek rovására. (Maassen 2017.) 22 vizsgált ország közül 12-ben jelentős változások történtek az egyetemi kormányzásban az utóbbi években. Ennek mozgatórugója általában a hatékonyságra való törekvés, az erőforrásokkal történő takarékoskodás, az adminisztratív terhek csökkentése (Pruvot-Estermann 2018).

\section{A külső tagok szerepe az egyetemirányitásban}

A boardok szerepének növekedése általában együtt járt a külső tagok hangsúlyosabb szerepével. Franciaországban például a külső tagok a belsőkével azonos jogosítványokat kaptak (Pruvot-Estermann 2018), Magyarországon pedig a konzisztóriumok birtokolnak jelentős hatásköröket. (A konzisztóriumokról részletesen lásd Rónay 2019a, 2019b, 2020.)

A külső tagok, a gazdaság és társadalom képviselőinek megjelenését az egyetemi kormányzásban egyrészt központi szabályozás írja elő (lásd a felsőoktatás-irányítás és a belső kormányzás összefüggéseiről szóló alfejezetben), másrészt az intézmények maguk is kezdeményezték külső szereplők bevonását a tevékenységeik minőségének javítása érdekében. A külső szereplők és testületeik elsősorban a stratégia, az intézményfejlesztés irányának meghatározásában, az intézményvezetés felügyeletében, pénzügyi kérdésekben, és néhány esetben a felsővezetők kinevezésében bírnak döntési hatáskörrel. Akadémiai kérdésekben és a napi müködés irányításában nincs meghatározó szerepük. (Arnhold et al. 2018.) A határok ugyanakkor - éppen a piaci viszonyok korábban tárgyalt erösödésével a felsőoktatásban - elmosódni látszanak a stratégiai, pénzügyi, valamint az akadémiai kérdések között. Angliában bizonyos egyetemeken az irányítás külső tagjai megpróbálnak utat találni a szenátusokhoz és bekapcsolódni az akadémiai döntéshozatalba; innen már nem sok kell ahhoz, hogy ezek a szereplők abba is beleszóljanak, hogy ki és mit tanít (Shattock 2019: 5).

Ami a külső tagok részvételét illeti az irányító testületekben, 2016-ban Lengyelország volt az egyetlen olyan állam, ahol nincs külső tag az egyetem irányításában (unitárius rendszer, zárt, szenátus jellegü testület). Ugyanakkor a lengyel egyetemek létesíthettek egyéb tanácsadó testületet, melynek összetételét szabadon határozhatták meg. (PruvotEstermann 2018.) 2018-ban azonban az új felsőoktatási törvény alapján a lengyel egyetemeken is létrejött az a testület, amelynek külső tagjai vannak (Eurydice 2019). A szenátus típusú testületekben elvétve fordul elő külső tag (csak Észtországban, Írországban és az Egyesült Királyságban), míg a board típusú testületekben mindenütt jelen vannak, sőt, a külső tagok vannak többségben. Vannak olyan államok, ahol a boardokban csak külső tagok vannak, ilyen Ausztria, Csehország, Hollandia és Szlovákia. A másik véglet Szerbia, ahol a board tagjainak csak egyötöde külső. Ami a külső tagok jellemzőit illeti, a legtöbben az üzleti szférából érkeznek. A második legnagyobb csoportot a nemzeti és helyi hatóságok képviselői jelentik, a harmadikat más egyetemek oktatói. A legritkábban a volt hallgatók jelennek meg a boardokban. (Pruvot-Estermann 2018.) 
Arnhold és szerzőtársai felhívják a figyelmet arra, hogy a külső szereplők pozitív hatását az intézmények müködésére jelentősen befolyásolja, hogy a valóságban milyen mértékben látják el a feladataikat. A tapasztalat azt mutatja, hogy nem minden esetben teszik ezt megfelelően. Az intézményeknek gyakran gondot okoz olyan, kellően motivált személyeket találniuk, akik hajlandók a szükséges erőfeszítésre. (OECD 2008, idézi Arnbold et al. 2018.)

\section{A belsö érintettek az egyetemirányitásban}

A külső tagok megjelenése mellett a hallgatók, az oktatók és a nem oktató dolgozók szerepe is érdekes a hatalmi viszonyok szempontjából. Az EUA által 2017-ben vizsgált országok/tartományok közül a hallgatók csak Hollandiában nem rendelkeznek képviselettel a döntéshozó testületekben. Az oktatók minden országban jelen vannak az irányító testületekben - vagy a szenátusban, vagy a boardban. A nem oktató dolgozók a vizsgált 22 ország közül Csehországban, Észtországban, Horvátországban, Szerbiában, Izlandon, Svédországban és Szlovákiában, azaz a felsőoktatási rendszerek egyharmadában nem rendelkeznek képviselettel (Pruvot-Estermann 2018); ennek a körnek a részvétele az egyetemirányításban tehát kevésbé általános.

\section{Összegzés}

Tanulmányunkban a felsőoktatás-irányítás és az egyetemi kormányzás legfontosabb jelenségeit és trendjeit tekintettük át Európában. Az eredmények azt mutatják, hogy bár az elmúlt évtizedben radikális változások nem következtek be az egyetemek irányításában - kivételt éppen Magyarország képez -, számos országban jellemző az útkeresés, illetve a finomhangolás. Erre utal az a tény is, hogy számos országban született új jogszabály, illetve törvénymódosítás a felsőoktatásra vonatkozóan. A teljesség igénye nélkül ilyen volt Franciaország, Olaszország, Portugália, az Egyesült Királyság, Dánia, Lettország, Litvánia, Svédország és természetesen Magyarország.

$\mathrm{A} z$ útkeresés a felsőoktatás-irányításban (rendszerszinten) többek között kiterjed az intézmények státusára (például alapítványi forma), finanszírozására (a gazdálkodási önállóság növelése, illetve csökkentése), a szabályozás diverzifikációjára (bizonyos intézmények kiemelt státusa), az egyetemi alkalmazottak foglalkoztatására (közalkalmazotti státus megszüntetése), az akkreditációra (intézményi akkreditáció, nemzetközi auditorok). A belső kormányzásban a boardok, és ezzel együtt a külső szereplők térnyerése és befolyásának bővülése tekinthető meghatározó tendenciának. A verseny fokozódása, a piaci szempontok hangsúlyosabb megjelenése azonban megkérdőjelezheti azt a hagyományos hatalommegosztást a boardok, egzekutív vezetők és adminisztratív egységek, valamint az akadémiai testületek és vezetők között, mely szerint az oktatással és kutatással összefüggő szakmai döntések az utóbbiak kezében vannak. A mai egyetemi világban a stratégiai, finanszírozási, hatékonysági kérdések olyan szorosan függnek össze az oktatással és a kutatással, hogy az az egyes szereplők közötti viszony újraértelmezését kívánja meg. 
— KECZER GABRIELLA: FELSŐOKTATÁS-IRÁNYÍTÁSI ÉS EGYETEMI KORMÁNYZÁSI TRENDEK... — — -

\section{IRODALOM}

Arnhold, N., Kivistö, J., Püttmann, V., Vossensteyn, H. \& Zielge, F. (2018) World Bank Support to Higher Education in Latvia. Volume 2: Internal Funding and Governance. Washington, World Bank. https://www.worldbank.org/en/country/eu/publication/ world-bank-support-to-higher-education-in-latvia [Letöltve: 2019. 10. 27.]

Barakonyi K. (2004) Egyetemi kormányzás. Merre tart Európa? Közgazdasági Szemle, Vol. 51. No. 6. pp. 584-599.

Bleiklie, I., Enders, B., Lepori \& Musselin, C. (2011) New Public Management, Network Governance and the University as a Changing Professional Organization. In: T. Christensen \& P. Laegreid (eds) The Ashgate Research Companion to New Public Management. Farnham, Ashgate. pp. 161-176.

Bleiklie, I. \& Kogan, M. (2007) Organization and Governance of Universities. Higher Education Policy, Vol. 20. pp. 477-493.

Braun, D. \& Merrien, F. (1999) Towards a Model of Governance for Universities? A Comparative View. London, Jessica Kingsley.

Capano, G., Regini, M. \& Turri, M. (2016) Changing Governance in Universities: Italian Higher Education in Comparative Perspective. London, Palgrave MacMillan.

Carvalho, T. (2018) Academic Perception of Governance and Management. In: J. C. Shin \& P. Teixeira (eds) Encyclopedia of International Higher Education Systems and Institutions. Dordrecht, Springer Science+Business Media.

Clark, B. R. (1998) Creating Entrepreneurial Universities. Oxford, Pergamon.

Donina, D. \& Paleari, S. (2018) University Governance Structures in Southern Europe: New Public Management-driven or Conceptual Stretching? https:/ecpr.eu/Filestore/ PaperProposal/ae668eac-2f1c-4195-9197-c1adde6e3e44.pdf [Letöltve: 2019. 12. 15.]

EUA (2015) University Leaders' Perspectives. Governance and Funding. European University Association, Brussels, Belgium. https://eua.eu/downloads/publications/university\%20 leaders\%20perspectives\%20governance\%20and\%20funding.pdf [Letöltve: 2019. 11. 28.]

Eurydice (2008) Higher Education Governance in Europe. Policies, Structures, Funding and Academic Staff. Brussels, Eurydice. http://eacea.ec.europa.eu/education/eurydice/ documents/thematic_reports/091EN.pdf [Letöltve: 2019. 12. 15.]

Eurydice (2019) National Reforms in Higher Education - Poland. https://eacea.ec.europa. $\mathrm{eu} /$ national-policies/eurydice/content/national-reforms-higher-education-50_en [Letöltve: 2020.01 .30$.

Gornitzka, A., Maassen, P. \& de Boer, H. (2017) Change in University Governance Structures in Continental Europe. Higher Education Quarterly, Vol. 71. No. 3. pp. 274 289.

Keczer G. (2010) Egyetemirányítás: lehetöségek és korlátok. Szeged, Egyesület Közép-Európa Kutatására.

KeCzer G. (2014) Az egyetemek szerepe, irányitása és müködése a 21. században: Felsöoktatáskutatási tanulmányok. Szeged, Egyesület Közép-Európa Kutatására.

KeCzer, G. (2015) University Governance in Western Europe and in the Visegrád Countries. In: J. Berács, J. Iwinska, G. Kováts \& L. Matei (eds) Central European Higher Education Cooperation Conference Proceedings. Budapest, Corvinus University of Budapest Digital Press. pp. 164-177.

Keczer, G. \& Kováts, G. (2019) Best Practice' Organizational and Management Solutions in Some Successful Higher Education Institutions. In: G. Kováts \& Z. Rónay (eds) 
In Search of Excellence in Higher Education. Budapest, Center for International Higher Education Studies Corvinus University of Budapest. pp. 41-70.

Kolster, R., Vossensteyn, J. J., de Boer, H. F. \& Jongbloed, B. W. A. (2016) Quick Scan: University Governance Structures, Appointments, and Student Participation in Europe. Enschede, Center for Higher Education Policy Studies.

Kováts G. (2016, ed.) A kancellári rendszer bevezetése a magyar felsöoktatásban. Tapasztalatok és várakozások. Budapest, Budapesti Corvinus Egyetem, Nemzetközi Felsőoktatási Kutatások Központja.

Kováts, G. (2018) Trust and the Governance of Higher Education: The Introduction of Chancellor System in Hungarian Higher Education. In: R. Pricopie, L. Deca \& A. Curaj (eds) European Higher Education Area: The Impact of Past and Future Policies. Berlin, Springer International Publishing. pp. 651-669.

Krücken, G. (2011) A European Perspective on New Modes of University Governance and Actorbood. Berkeley (CA), Center for Studies in Higher Education. http://www.cshe. berkeley.edu/sites/default/files/shared/publications/docs/ROPS.Kruecken.EuroView.12.13.11.pdf [Letöltve: 2019. 12. 15.]

Manssen, P. (2017) The University's Governance Paradox. Higher Education Quarterly, Vol. 71. No. 3. pp. 290-298.

McLendon, M. K., Hearn, J. C. \& Deaton, R. (2006) Called to Account: Analyzing the Origins and Spread of State Performance-Accountability Policies for Higher Education. Educational Evaluation and Policy Analysis, Vol. 28. No. 1. pp. 1-24.

Middlehurst, R. (2004) Changing Internal Governance: A Discussion of Leadership Roles and Management Structures in UK Universities. Higher Education Quarterly, Vol. 58. No. 4. pp. 258-279.

OECD (2008) Tertiary Education for the Knowledge Society. Thematic Review of Tertiary Education. Paris, OECD.

Pruvot, E. B. \& Estermann, T. (2017) University Autonomy in Europe III. The Scorecard 2017. European University Association, Brussels, Belgium.

Pruvot, E. B. \& Estermann, T. (2018) University Governance: Autonomy, Structures and Inclusiveness. In: R. Pricopie, L. Deca \& A. Curaj (eds) European Higher Education Area: The Impact of Past and Future Policies. Berlin, Springer International Publishing. pp. 619-638.

RóNAY Z. (2019a) A konzisztórium helye, szerepe, működésének célja az állami felsőoktatási intézmények irányításában és vezetésében - kérdések és válaszkísérletek. In: JuHÁsz E. \& Endrődy O. (eds) Oktatás-Gazdaság-Társadalom. Budapest-Debrecen, Magyar Nevelés- és Oktatáskutatók Egyesülete (HERA) - Debreceni Egyetem. pp. 752-765.

Rónay Z. (2019b) Consistory - The Obscure Subject of State Control. In: Kováts G. \& Rónay Z. (eds) In Search of Excellence in Higher Education. Budapest, Corvinus University of Budapest Digital Press. pp. 71-87.

RónAy Z. (2020) Vezetök, testületek, felelösség a felsőoktatási intézményekben. Budapest, L'Harmattan.

Sнаттоск, M. (2019) University Governance and Academic Work: The 'Business Model' and Its Impact on Innovation and Creativity. Centre for Global Higher Education Working paper no. 48. https://www.researchcghe.org/publications/working-paper/universitygovernance-and-acade-mic-work-the-business-model-and-its-impact-on-innovation-andcreativity/ [Letöltve: 2019. 11. 28.]

Stensaker, B. \& Harvey, L. (2001) Accountability in Higher Education. Routlege, New York. 
Tapanila, K., Sirvonen, P. \& Filander, K. (2018) Academics' Social Positioning Towards the Restructured Management System in Finnish Universities. Studies in Higher Education, Vol. 45. No. 1. pp. 117-128.

Teichler, U. (2019) Steering in a Modern Higher Education System: The Need for Better Balances between Conflicting Needs and Expectations. International Centre for Higher Education Research. Kassel. https://www.unikassel.de/einrichtungen/fileadmin/datas/ einrichtungen/incher/PDFs/Working_Paper11_2019.pdf [Letöltve: 2019.11.28.]

Van Vught, F. (1994) Autonomy and Accountability in Government/University Relationships. In: J. Salmi \& A. M. Verspoor (eds) Revitalizing Higher Education. Oxford, IAU Press.

A cikk a Creative Commons Attribution 4.0 International License (https://creativecommons.org/licenses/ by/4.0/) feltételei szerint publikált Open Access közlemény, melynek szellemében a cikk bármilyen médiumban szabadon felhasználható, megosztható és újraközölhető, feltéve, hogy az eredeti szerző és a közlés helye, illetve a CC License linkje és az esetlegesen végrehajtott módosítások feltüntetésre kerülnek. (SID_1) 